AGRICULTURE AND BIOLOGY JOURNAL OF NORTH AMERICA

ISSN Print: 2151-7517, ISSN Online: 2151-7525, doi:10.5251/abjna.2011.2.1.101.108

(C) 2011, ScienceHu $\beta$, http://www.scihub.org/ABJNA

\title{
Assessing the level of soil nutrients: a case study of Donga, Ibi and Wukari farmlands in Taraba State, Nigeria
}

\author{
S.G. Zaku ${ }^{1 *}$, S.A. Emmanuel ${ }^{1}$ and S.A.Thomas ${ }^{1}$ \\ ${ }^{1}$ Chemistry Advance Laboratory, Sheda Science and Technology Complex, P.M.B.186, \\ Garki, Abuja FCT, Nigeria, Email: zakusamaila@yahoo.com \\ ABSTRACT
}

\begin{abstract}
Physical and chemical properties of the soil samples from the three regions; Donga, Ibi and Wukari in the southern part of Taraba State, Nigeria were determined. These are colour, $\mathrm{pH}$, and conductivity while the mineral compositions investigated (soil nutrients) were $\mathrm{N}, \mathrm{P}, \mathrm{K}, \mathrm{Ca}, \mathrm{Mg}, \mathrm{Fe}$, $\mathrm{Na}, \mathrm{Mn}$ and $\mathrm{Zn}$ by highly sensitive methods. The $\mathrm{pH}$ ranges from $6.1-6.8,6.2-6.8,6.1-6.8$ at Donga, Ibi and Wukari respectively. The conductivity ranges from $0.72-1.65 \times 10^{2} \mu \mathrm{S} / \mathrm{cm}, 0.78-$ $2.58 \times 10^{2} \mu \mathrm{S} / \mathrm{cm}, 0.57-1.90 \times 10^{2} \mu \mathrm{S} / \mathrm{cm}$ respectively. The results indicated that Donga and Wukari had relatively higher nutrients than Ibi. However $\mathrm{Mn}$ and $\mathrm{Zn}$ were absent in some locations of the study areas but at Ibi Zn was not detected at any of the sample site.
\end{abstract}

Keywords: Soil nutrient, Soil colour, $\mathrm{pH}$, Conductivity

\section{INTRODUCTION}

As global concerns focus on environmental protection, natural resources management and the world's ability to feed ever-growing populations, the interdependent between nations and scientific disciplines is becoming increasingly greater then ever before (Swift and Woomer, 1994). The increased need to produce greater amounts of foods and fibre for the World's population has necessitated the development of appropriate technologies to maintain and improve soil fertility. This is particularly so in tropical countries where population growth is highest in the world and yet soils tend to be more highly weathered and have low inherent fertility (Sanchez, 1976).

In Africa, food production per capita has decreased in the past decade, whereas the continent's population has increased significantly in the same manner (Higgins and Kassam, 1980). Most of these soils have serious constraints which must be overcome in order to improve their productivity for sustainable agriculture. The Soil Society of America (1995) defines soil quality as "the capacity of a specific kind of soil to function within the natural or managed ecosystem boundaries, to sustain plant and animal productivity, maintain or improve water and air quality and support human health and habitation"( Lal. R., 1995). With the growing dependence on agricultural production in arid and semiarid regions, use of fertilizers has increased tremendously. Ironically, more fertilizers are being applied than before, but agricultural production problems are, in general, getting worse (Higgins and Kassam, 1980). An important reason, yet little understood, is the improper use of fertilizers when it comes to kind and application rate (Bashour, 2001). The problem arises partly from the lack of proper methods of soil analysis that reflects the actual soil status, and partly from the misunderstanding of what a fertilizer really is, how it should be used, and for what purpose (AlKharusi et al., 2009 and Mclean, 1982).

The selected study areas in this word are inhabited by communities which frequently engage in farming activities that are of commercial benefit and sources of their major income. The farming activity is done year in and year out. This has led to a decrease in the soil fertility, resulting in a low agricultural yield as compared to the previous years of farming. Therefore, it is important to assess the soil physical and chemical properties to ascertain the nutrient level so as to make appropriate suggestions on what kind of soil remedy to apply in order to improve the soil fertility for optimum yield.

\section{MATERIALS AND METHODS}

Study Area: The study areas are Donga, Ibi and Wukari farm lands. Figure 1 below is the sketch map of Taraba State of Nigeria showing the three Local governments of the study areas and figure 2 the map showing sampling locations in the three areas. 
Agric. Biol. J. N. Am., 2011, 2(1): 101-108

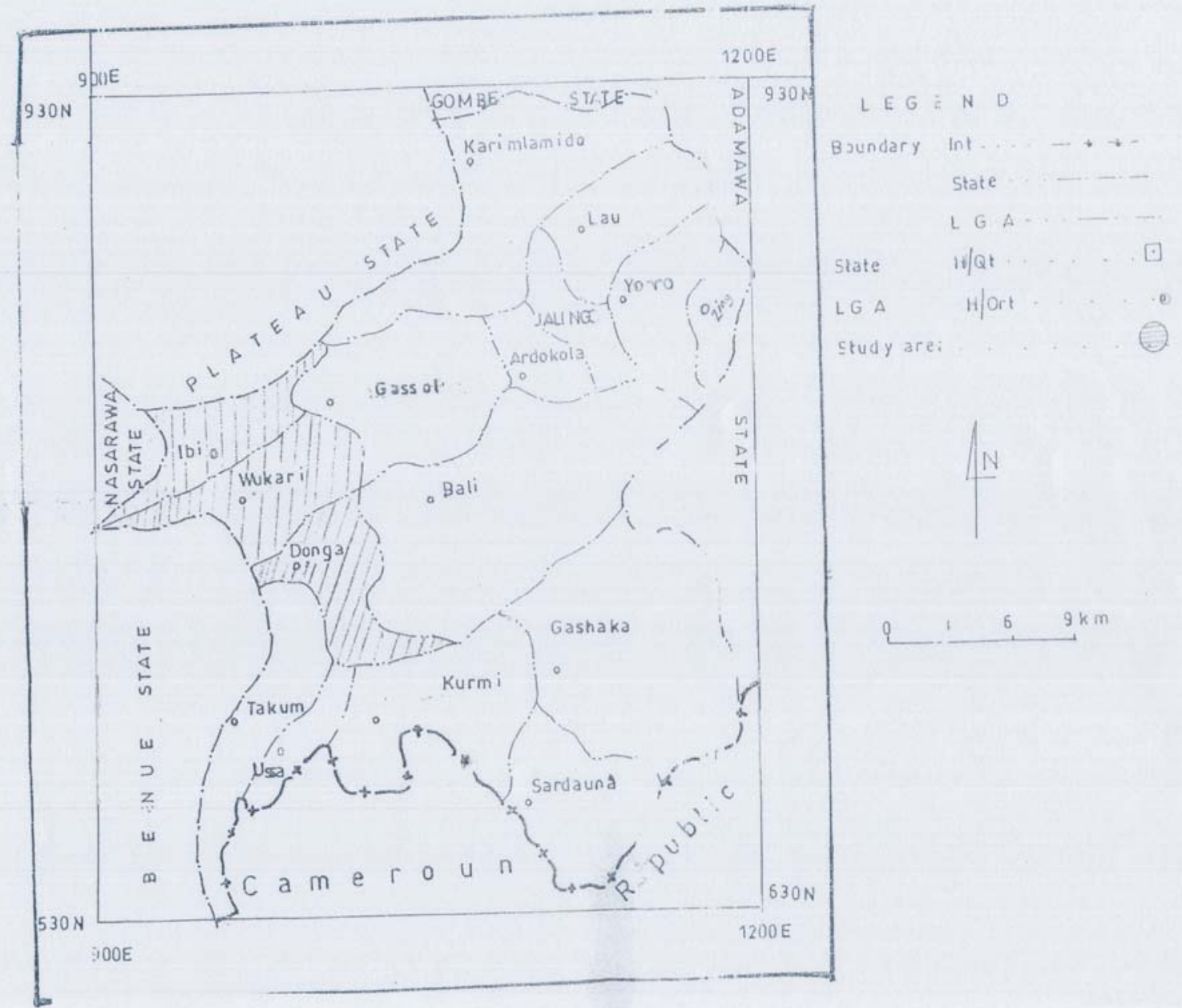

Figure 1: Map of Taraba State showing the study area. 
Agric. Biol. J. N. Am., 2011, 2(1): 101-108

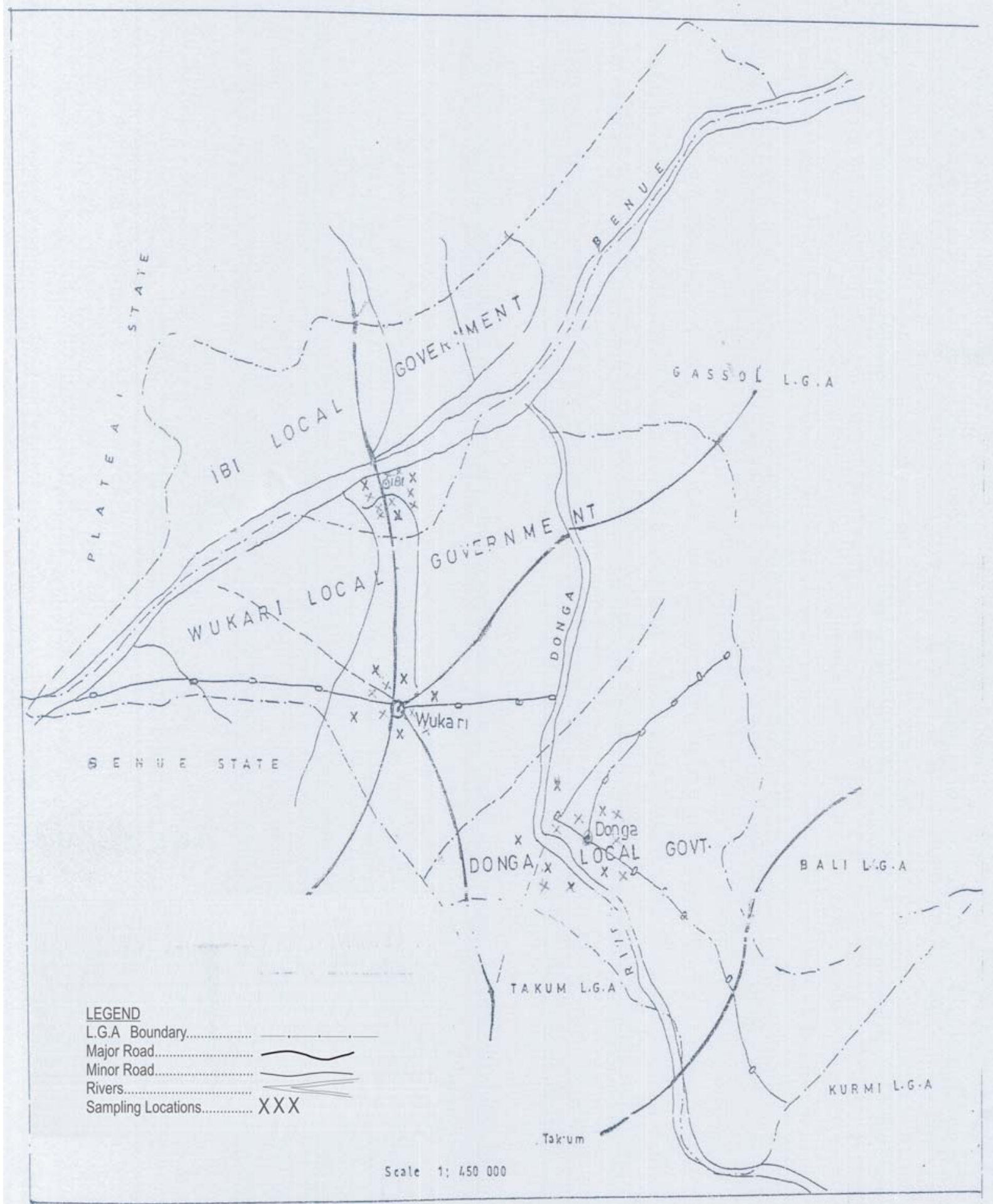

Figure 2: Map of study area indicating sampling location 
Field sampling: Each of the farm land was divided into ten directions, eight hundred meters away in each direction. Samples were taken from $0-15 \mathrm{~cm}$ depth at five spots at $10 \mathrm{~m}$ apart. The five soil samples were then mixed to form a composite soil sample for each direction respectively (North A, North East B, East C, South East D, South E, Southwest F, Southwest west G, West H, Northwest I ). Also at the center ( $\mathrm{J}$ ) of each farm soil, samples were taken similarly from five spots and mixed to form a composite sample for the centre.

Sample preparation: The soil samples collected from the field were mixed thoroughly well and air dried in the laboratory. The composite soil samples were sieved each through a $2 \mathrm{~mm}$ mesh sieve before test samples were then obtained by coning and quartering method (sexana, 1990). About $2 \mathrm{~g}$ of dried sample was digested in each case.

Soil colour determination: Soil colour was determined by comparing the soil colour in its field condition to a series of coloured chips in a booklet called Munsell soil colour chart. Each chip is described uniquely by its position on three simple axes of colour-hue, value, and chroma by a descriptive term applied to a range of chips (Munsell, 1973).

Conductivity Measurement: Five grams of fresh soil was weighed from which stones and larger materials were removed and placed in a $100 \mathrm{~cm}^{3}$ beaker, $40 \mathrm{~cm}^{3}$ distilled water was added and stirred vigorously with a glass rod. This was allowed to stand for 5 minutes for equilibration.

pH measurement: The soil preparation was the same for conductivity measurement. The $\mathrm{pH}$ meter was calibrated with two buffer solutions ( $\mathrm{pH} 4$ and 9).

\section{Minerals analysis:}

Two grams of each dried ground soil samples were placed in a $200 \mathrm{ml}$ kjeldahl digestion flask. $5 \mathrm{ml}$ of conc. $\mathrm{HNO}_{3}$ and $1 \mathrm{ml}$ of conc. $\mathrm{HCl}$ were added. The digestion flask was heated on a heating mantle in a fume cupboard until white fumes were seen. The mixture was then cooled and $10 \mathrm{ml}$ distilled/deionised water was added. This was filtered using a whatman filter paper $(110 \mathrm{~mm})$ into a $100 \mathrm{ml}$ volumetric flask and made up to the mark with distilled/deionised water. Working standard solutions of $\mathrm{Ca}, \mathrm{Mg}, \mathrm{Fe}, \mathrm{Mn}$ and $\mathrm{Zn}$ were prepared from stock standard solution (1000ppm) and absorbance was obtained for each element in the samples using atomic absorption spectrometer (AAS) 969 UNICAM (Scott et al., 1971).
The concentrations of the samples were obtained by calibration curve of standard solutions. The concentration of nitrogen was determined by Kjeldahl method and phosphorus by spectrometry (Jeffery et al., 1989) while Sodium and potassium by flame photometer (Golterman, 1996).

\section{DISCUSSION}

Soil colours: The colour results of the soils are shown in Table 1. Donga samples A,C, D,E, H, I were found to be dark brown, brown, reddish brown in colour. This suggests the presence of nonhydrated iron oxide called haematite $\mathrm{Fe}_{2} \mathrm{O}_{3}(\mathrm{Ahn}, 1970)$ in the soil. Samples B showed pinkish gray, black and weak red. These colours are due to hydrated ferrous ion ( $\left.\mathrm{Fe}(\mathrm{OH})_{2}\right)$, organic matter and haematite in the soil. The colour results for Donga soil samples indicate good drainage and moderate levels of iron in the soil.

For Ibi soils, samples A and I showed reddish yellowish and light red colours respectively. These colours indicate the presence of goethite $\left(\mathrm{Fe}_{2} \mathrm{O}_{3} \cdot \mathrm{H}_{2} \mathrm{O}\right)$. The pinkish gray and reddish yellow colours were observed in samples $\mathrm{D}$ and $\mathrm{J}$, which were due probably to the removal of free ion under reducing conditions (Lorch, 1991). The light brown and reddish brown colours were observed in samples $\mathrm{C}, \mathrm{F}$ and $\mathrm{G}$ which indicates the presence of limonite $\left(\mathrm{Fe}_{2} \mathrm{O}_{3} \cdot 1 / 2 \mathrm{H}_{2} \mathrm{O}\right)$, (Ahn, 1970). Wukari soil samples $\mathrm{A}$ and $\mathrm{B}$ were black in colour, which indicates the presence of high levels of organic matter in the soil. Samples $C$ and $E$ were dark brown and samples $F$, $\mathrm{G}, \mathrm{H}$ and $\mathrm{J}$ were weak red in colour which suggests the presence of haematite. Sample D had a very dark grayish colour. This indicates organic matter in the soil.

Soil $\mathbf{p H}$ : The $\mathrm{pH}$ of the soil samples are presented in Table 2. The $\mathrm{pH}$ ranges of the soil samples for, Donga, Ibi and Wukari were 6.1 - 6.8, $6.2-6.8$ and $6.1-6.8$ respectively. The ranges indicate the soils to be slightly acidic, however, the $\mathrm{pH}$ of most mineral soils range from 5.5 - 7.5 (Radujevic and Bechkin, 1999). Radujevic and Bechkin (1999) explained that acidic soils with $\mathrm{pH}$ from 4.0 to 5.5 can have high concentration of soluble aluminum and manganese ions, which may be toxic to the growth of some plant. Winterhalder (1984) stated that toxicity may rise if $\mathrm{pH}$ is below 5 and also reported that a $\mathrm{pH}$ range of approximately 6 to 7 can release most readily available plant nutrients. The $\mathrm{pH}$ values of these soils indicate the study areas have the required range for plant growth. 
Agric. Biol. J. N. Am., 2011, 2(1): 101-108

RESULTS

Table 1: Soil colours of study areas (Dry sample)

\begin{tabular}{|c|c|c|c|c|c|c|}
\hline \multirow[b]{2}{*}{ Sample } & \multicolumn{2}{|c|}{ Donga } & \multicolumn{2}{|c|}{ Ibi } & \multicolumn{2}{|c|}{ Wukari } \\
\hline & Soil colour name & $\begin{array}{c}\text { Standard } \\
\text { notation }\end{array}$ & Soil colour name & Standard notation & Soil colour name & $\begin{array}{c}\text { Standard } \\
\text { notation }\end{array}$ \\
\hline A & DarkBrown & 7.5YR 3/2 & Reddish Yellow & 5YR 6/6 & Black & $5 Y 2.5 / 2$ \\
\hline$B$ & Pinkish gray & $7.5 Y R 7 / 2$ & Dusky red & $10 \mathrm{R} 3 / 2$ & Black & $2.5 Y R 4 / 0$ \\
\hline C & Dark brown & $7.5 Y R$ 4/4 & Light brown & $7.5 Y R 6 / 4$ & Dark grayish brown & $2.5 Y 4 / 2$ \\
\hline $\mathrm{D}$ & Brown & 7.5YR 5/2 & pinkish gray & 5YR 7/2 & Dark reddish gray & $2.5 Y R$ 4/2 \\
\hline$E$ & Dark reddish gray & $7.5 Y R 3 / 2$ & Brown & 7.5 YR 5/4 & Dark brown & 7.5YR 4/4 \\
\hline $\mathrm{F}$ & Brown & 7.5YR 5/4 & Reddish brown & $5 Y R 5 / 3$ & Weak red & 10R 5/3 \\
\hline $\mathrm{G}$ & Dark reddish brown & $5 Y R 3 / 2$ & Reddish brown & 5YR 4/4 & Weak red & 10R $4 / 4$ \\
\hline $\mathrm{H}$ & Reddish brown & 5YR5/3 & Dark brown & 7.5YR 4/4 4/2 & Weak red & $2.5 \mathrm{YR}$ \\
\hline 1 & Reddish brown & 5YR 4/4 & Yellowish red & 5YR 5/6 & Reddish brown & 5YR 4/4 \\
\hline $\mathrm{J}$ & Reddish brown & 5YR 5/4 & Reddish gray & $\begin{array}{c}\text { 5YR 5/2 } \\
5 / 4\end{array}$ & Weak red & 10R \\
\hline
\end{tabular}

Table 2: Physicochemical properties of the soils.

\begin{tabular}{|c|c|c|c|c|c|c|}
\hline \multirow[b]{2}{*}{ Sample } & \multicolumn{2}{|c|}{ Donga } & \multicolumn{2}{|c|}{ Ibi } & \multicolumn{2}{|c|}{ Wukari } \\
\hline & $\mathrm{pH}$ & $\begin{array}{l}\text { Conductivity } \\
\left(\times 10^{2} \mu S / \mathrm{cm}\right)\end{array}$ & pH & $\begin{array}{c}\text { Conductivity }\left(\times 10^{2}\right. \\
\mu \mathrm{S} / \mathrm{cm})\end{array}$ & pH & $\begin{array}{c}\text { Conductivity (x10 } \\
\mu \mathrm{S} / \mathrm{cm})\end{array}$ \\
\hline$A$ & 6.6 & 1.47 & 6.3 & 2.20 & 6.2 & 1.11 \\
\hline$B$ & 6.1 & 0.96 & 6.4 & 2.58 & 6.6 & 0.96 \\
\hline $\mathrm{C}$ & 6.4 & 0.72 & 6.4 & 1.05 & 6.1 & 1.05 \\
\hline $\mathrm{D}$ & 6.3 & 1.26 & 6.8 & 0.78 & 6.3 & 1.08 \\
\hline$E$ & 6.4 & 0.81 & 6.4 & 1.47 & 6.8 & 1.86 \\
\hline $\mathrm{F}$ & 6.6 & 0.87 & 6.5 & 0.93 & 6.6 & 1.14 \\
\hline G & 6.8 & 0.81 & 6.4 & 0.78 & 6.4 & 1.14 \\
\hline $\mathrm{H}$ & 6.6 & 1.02 & 6.3 & 0.50 & 6.2 & 0.57 \\
\hline I & 6.8 & 1.65 & 6.2 & 0.96 & 6.7 & 1.90 \\
\hline $\mathrm{J}$ & 6.8 & 0.87 & 6.6 & 1.08 & 6.7 & 1.08 \\
\hline Range & $6.1-6.8$ & $0.72-1.65$ & $6.2-6.8$ & $0.78-2.58$ & $6.1-6.8$ & $0.57-1.90$ \\
\hline$x$ & 6.5 & 1.04 & 6.4 & 1.23 & 6.5 & 1.19 \\
\hline $\pm S$ & 0.22 & 0.30 & 0.16 & 0.63 & 0.24 & 0.38 \\
\hline
\end{tabular}

The results are means of triplicate determinations \pm standard deviation 
Agric. Biol. J. N. Am., 2011, 2(1): 101-108

Table 3a: Phosphorus, P (mg/kg) and Nitrogen, $\mathrm{N}(\%)$ content of the soil samples.

\begin{tabular}{|c|c|c|c|c|c|c|}
\hline & \multicolumn{2}{|c|}{ Donga } & \multicolumn{2}{|c|}{ Ibi } & \multicolumn{2}{|c|}{ Wukari } \\
\hline Sample & $\mathbf{P}$ & $\mathbf{N}$ & $\mathbf{P}$ & $\mathbf{N}$ & $\mathbf{P}$ & $\mathbf{N}$ \\
\hline A & 6.75 & 0.38 & 8.35 & 1.72 & 5.38 & 0.26 \\
\hline B & 6.99 & 0.79 & 7.34 & 0.59 & 6.45 & 1.18 \\
\hline $\mathrm{C}$ & 7.83 & 0.95 & 6.87 & 0.55 & 4.67 & 0.36 \\
\hline $\mathrm{D}$ & 5.24 & 0.43 & 5.60 & 0.53 & 5.28 & 0.91 \\
\hline$E$ & 4.87 & 0.61 & 4.22 & 0.49 & 4.92 & 0.34 \\
\hline $\bar{F}$ & 8.67 & 1.10 & 3.97 & 0.47 & 4.33 & 0.39 \\
\hline $\mathrm{G}$ & 7.26 & 0.79 & 6.98 & 1.20 & 4.66 & 0.37 \\
\hline $\mathrm{H}$ & 6.29 & 0.45 & 4.63 & 0.49 & 5.76 & 0.44 \\
\hline I & 7.34 & 0.58 & 3.73 & 0.41 & 4.99 & 0.50 \\
\hline $\mathrm{J}$ & 6.88 & 0.49 & 4.49 & 0.63 & 5.54 & 0.76 \\
\hline$x$ & 6.81 & 0.66 & 5.62 & 0.71 & 5.20 & 0.55 \\
\hline $\pm S$ & 1.07 & 0.23 & 1.56 & 0.40 & 0.59 & 0.28 \\
\hline
\end{tabular}

The results are means of triplicate determinations \pm standard deviation

Table 3b: Metal contents of the soil samples for $\mathrm{Ca}, \mathrm{Mg}, \mathrm{K}$ and $\mathrm{Na}$ (cmol/kg).

\begin{tabular}{|c|c|c|c|c|c|c|c|c|c|c|c|c|}
\hline & \multicolumn{4}{|c|}{ Donga } & \multicolumn{4}{|c|}{ Ibi } & \multicolumn{4}{|c|}{ Wukari } \\
\hline Sample & $\mathrm{Ca}$ & $\mathrm{Mg}$ & $\mathrm{K}$ & $\mathrm{Na}$ & $\mathrm{Ca}$ & $\mathrm{Mg}$ & $\mathrm{K}$ & $\mathrm{Na}$ & $\mathrm{Ca}$ & $\mathrm{Mg}$ & $\mathrm{K}$ & $\mathrm{Na}$ \\
\hline$A$ & 0.61 & 24.83 & 0.95 & 1.72 & 0.90 & 0.92 & 0.53 & 2.31 & 0.96 & 2.48 & 0.40 & 0.50 \\
\hline B & 2.96 & 30.13 & 0.54 & 0.50 & 0.70 & 0.74 & 0.27 & 1.17 & 0.30 & 0.94 & 0.19 & 1.17 \\
\hline $\mathrm{C}$ & 0.94 & 5.21 & 0.81 & 1.17 & 0.49 & 3.66 & 0.40 & 1.17 & 0.70 & 2.48 & 0.40 & 2.31 \\
\hline D & 6.96 & 13.92 & 0.19 & 1.17 & 0.99 & 3.40 & 0.95 & 1.72 & 1.40 & 3.01 & 0.19 & 0.50 \\
\hline$E$ & 13.94 & 2.58 & 0.40 & 1.72 & 0.64 & 1.75 & 1.63 & 0.50 & 1.40 & 0.52 & 0.19 & 1.17 \\
\hline $\mathrm{F}$ & 13.94 & 7.38 & 0.54 & 0.50 & 1.10 & 1.08 & 4.90 & 1.17 & 1.59 & 1.39 & 0.54 & 1.72 \\
\hline G & 15.94 & 3.75 & 0.19 & 2.31 & 0.38 & 0.15 & 0.54 & 1.17 & 1.59 & 0.26 & 0.19 & 2.93 \\
\hline $\mathrm{H}$ & 15.93 & 2.58 & 0.81 & 1.17 & 1.30 & 2.51 & 0.81 & 0.50 & 0.96 & 0.74 & 0.19 & 2.31 \\
\hline I & 0.96 & 7.86 & 0.54 & 0.50 & 1.59 & 0.67 & 0.40 & 0.50 & 1.02 & 0.38 & 0.40 & 2.31 \\
\hline $\mathrm{J}$ & 3.80 & 0.84 & 0.40 & 0.30 & 1.77 & 2.25 & 0.81 & 1.72 & 0.10 & 0.26 & 0.54 & 0.50 \\
\hline $\bar{X}$ & 7.60 & 9.91 & 0.54 & 1.11 & 0.99 & 1.71 & 1.12 & 1.19 & 1.00 & 1.25 & 0.32 & 1.54 \\
\hline $\pm S$ & 6.27 & 9.53 & 0.24 & 0.63 & 0.44 & 1.14 & 1.31 & 0.57 & 0.49 & 0.99 & 0.14 & 0.85 \\
\hline
\end{tabular}

The results are means of triplicate determinations \pm standard deviation 
Agric. Biol. J. N. Am., 2011, 2(1): 101-108

Table 3c: Metal contents of the soil samples for Fe, Mn, and Zn (mg/kg).

\begin{tabular}{|c|c|c|c|c|c|c|c|c|c|}
\hline 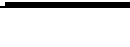 & \multicolumn{3}{|c|}{ Donga } & \multicolumn{3}{|c|}{ Ibi } & \multicolumn{3}{|c|}{ Wukari } \\
\hline Sample & $\mathrm{Fe}$ & $\mathrm{Mn}$ & $\mathrm{Zn}$ & $\mathrm{Fe}$ & $\mathrm{Mn}$ & $\mathrm{Zn}$ & $\mathrm{Fe}$ & $\mathrm{Mn}$ & $\mathrm{Zn}$ \\
\hline A & 34.93 & - & 5.08 & 38.65 & 5.32 & - & 42.53 & - & - \\
\hline$B$ & 18.13 & - & 5.00 & 41.06 & 5.40 & - & 13.59 & - & - \\
\hline C & 38.65 & 5.32 & 4.48 & 45.32 & - & - & 10.39 & - & - \\
\hline $\mathrm{D}$ & 16.53 & 4.82 & 4.52 & 20.12 & - & - & 10.66 & - & - \\
\hline $\mathrm{E}$ & 17.33 & 4.82 & 5.08 & 15.88 & - & - & 11.72 & - & - \\
\hline $\mathrm{F}$ & 17.33 & - & 5.00 & 25.24 & - & - & 11.19 & - & - \\
\hline G & 30.38 & 5.40 & 5.00 & 16.93 & - & - & 13.32 & - & 5.31 \\
\hline $\mathrm{H}$ & 39.74 & 5.60 & 4.48 & 27.72 & 5.72 & - & 12.78 & - & - \\
\hline I & 31.47 & - & 5.00 & 10.39 & - & - & 12.78 & - & 5.32 \\
\hline $\mathrm{J}$ & 27.72 & - & 4.48 & 36.46 & 7.96 & - & 12.26 & 4.40 & 6.00 \\
\hline $\mathrm{X}$ & 27.22 & 2.50 & 4.81 & 27.78 & 2.44 & 0.00 & 15.12 & 0.44 & 1.66 \\
\hline $\pm S$ & 8.76 & 2.51 & 0.26 & 11.42 & 3.07 & 0.00 & 9.19 & 1.32 & 2.55 \\
\hline
\end{tabular}

The results are means of triplicate determinations \pm standard deviation 
Conductivity of the soil: Soil conductivity values of the samples are presented in Table 3. Donga, Ibi and Wukari soils ranges from 0.57 to $1.90\left(\times 10^{2} \mu \mathrm{S} / \mathrm{cm}\right)$ which fall within the normal range $(0-2000 \mu \mathrm{S} / \mathrm{cm})$ reported by Lorch (1991). The result of the metals analyzed showed that the three studies areas had moderate concentration of metals evaluated in the soil and may account for the low conductivity.

Minerals Analysis: The soils of the three study areas (Donga, Ibi, Wukari) appears nutritionally suitable for cropping from the results obtained. The soil colours (Table 1 ) show good texture and minerals contents. Total- $\mathrm{N}$ content (Table $3 \mathrm{a}$ ) was high and sodium (Table3b) especially in Wukari soils, but $\mathrm{K}$ was low. Phosphorus contents (Table 3a) was moderate for plant growth while the exchangeable cations (Table $3 \mathrm{~b}$ ) were low, particularly $\mathrm{Ca}$ and $\mathrm{Mg}$ in some locations. The micro element contents of $\mathrm{Fe}$ (Table $3 c$ ) seem to be high while $\mathrm{Zn}$ and $\mathrm{Mn}$ are deficient in some areas of Donga and Wukari. Zinc was not detected in Ibi soil. All the mineral contents except that of $\mathrm{K}$ and $\mathrm{Zn}$ could be considered adequate for maximum growth of most tropical crops (Adeoye and Agboola, 2005).

\section{CONCLUSION AND RECOMMENDATIONS:}

The values of the physical parameters of the soils viz colours, $\mathrm{pH}$ and conductivity studied were within the recommended values accepted for plant growth ( Winterhalder (1984), Radujevic and Bechkin (1999) ). The minerals studied were appreciable except for the micro elements $\mathrm{Zn}$ and $\mathrm{Mn}$ that were deficient in some areas of the study. Also the sodium level was significantly high in Wukari soil, probably because Wukari is known to have salt deposits in some parts. The trends of the minerals concentrations showed mark differences in the three study areas. This observation is probably due to differences in their natural amounts and contributions from anthropogenic activities, leaching, wash-off and plant uptakes (Alloway, 1990). Based on the results of this study, the three areas were not nutrients depleted but little improvement or amendment of the soils is needed to replace the used up, leached and washed away nutrients. That can be achieved through use of fertilizers such as NPK, Urea, potassium oxide, super phosphate, animal and compost manure.

\section{REFERENCES}

Adeoye, D.A and A.A. Agboola, (2005). Critical levels of soil plant available $\mathrm{P}, \mathrm{K}, \mathrm{Zn}, \mathrm{Mg}, \mathrm{Cu}$ and $\mathrm{Mn}$ on maize leaf content in sedimentary soils of southwest Nigeria. Fert.Res., 6: 66 -71.

Alloway B.J.Ed(1990). Heavy Metals in Soil, Halsted Press,New York 35- 44, 197 - 221

Al-khanrusi,L.M, M.O. Elmardi, A. Ali, F.A.J. Al-said, K.M. Albdelbasit and S. Al-Rawali, 2009. Effect of mineral and organic fertilizers on the chemical characteristics and quality of date fruits.Int.J.Agric.Biol, 11:290 - 296.

Bashour,L.L. (2001). Fertility and fertilizer requirements. In Rural Integrated Development of the Mountains of Northern Lebanon. FAO Report to Ministry of Agriculture, Beirut, Lebanon.

Golterman,H.I.Clymo., Ohnstad.M.A.N. (1978). Method for physical and chemical analysis of fresh water, $2^{\text {nd }}$ Edition, Black Science, London, pp 88

Higgins I.J and Kassam B. (1980) In: Greenland D.J. (1981). Characterization of soils in Relation to their Classification and Management". Clarendo Press, oxford.pp135 - 137.

Jeffry,K.M., Nielsen,S. (1997). Vogels Textbook of Qualitative Chemical Analysis, $5^{\text {th }}$ Edition, Longman Group Ltd, London UK. pp 349

Lal, R. (1995). Sustainable Management of Soil Resources in the Humid Tropic United Nations University Press, New York, USA pp 610, 55 - 60

Mclean,E.V., 1982. Aluminium, In: page, A, L., R.L. Miller and D.R. Keeney(eds.),Methodsof soil Analysis, part 2, pp: 977- 999. American society Agronomy, Madison, Wisconsin.

Munsell (1973), Munsell Soil Colour Chart, Machetch Division of Kollomorgen Corporation Balttimore, Maryland $21218 \mathrm{pp}$ 1- the end

Radujevi,M. and Bechkin,(1990), Soil Sludge and Dust Practical Environmental Analysis, The Royal Society of Chemistry Cambridge, UK pp 138 - 150, $303-313$

Sexana,M.M (1990), Environmental Analysis of water, Soils and Air, Agro Botanoc Publisher, India pp121 - 129.

Scott,R.O.R.L., Mitchelt,.D., Purves and R.C, VOSS (1971). Spectro Chemical Metthods for the Analsis of Soils, Plant and other Agricultural Materials. Consultative Committee for Development of Spectrochemical Work, Bulletin No.2. The Macaulay Inst. For soil research, Aberdeen 8.

Swift, M. J. Woomer (1994), The Biological Management of Tropical Soil Fertility, John Willey and Son, Baffins Lane, Chichester, West Sussex United Kindom, pp 113

Winterhalder (1965), Metals in the environment: pollution Biology, 381: 9 Edmonton, Alberta,UK. 